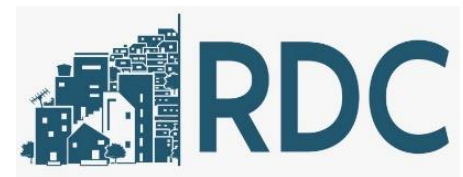

\title{
A ALPHAVILLE URBANISMO E O ORDENAMENTO JURÍDICO PÁTRIO: DA ILEGALIDADE PARA
} APARENTE LEGALIDADE

The Alphaville Urbanismo And The Legal Order Of The Homeland: From Illegality To Apparent Legality

\section{Cristina Pereira Araujo}

Universidade Federal de Pernambuco - UFPE, Recife, PE, Brasil

Lattes: http://lattes.cnpq.br/8068366194146208 Orcid: https://orcid.org/0000-0001-9986-5394

E-mail:crisaraujo.edu@gmail.com

\section{Leon Delácio Silva}

Procuradoria Geral do Município de João Pessoa, Jõao Pessoa,PB, Brasil

Lattes: http://lattes.cnpq.br/6599944561183448 Orcid: https://orcid.org/0000-0001-8025-0912

E-mail:leondelacio@yahoo.com.br

Trabalho enviado em 17 de julho de 2020 e aceito em 06 de agosto de 2021

\section{(c) (i)}

This work is licensed under a Creative Commons Attribution 4.0 International License. 


\section{RESUMO}

O objetivo do presente artigo é compreender o modo de operação próprio da empresa Alphaville Urbanismo S.A à luz do sistema normativo nacional, buscando verificar sua (i)legalidade. $O$ interesse do artigo decorreu da constatação de possíveis retrocessos socioambientais na aprovação e execução dos empreendimentos da Alphaville, quando comparados com os loteamentos tradicionais (abertos), regidos pela Lei Federal no 6.766/79, que são obrigados a doar áreas ao Poder Público, para uso da população em geral. Foi imprescindível fazer o cotejo do objeto deste artigo com as normas e princípios do Direito, inclusive com os novos institutos criados pela Lei Federal $n^{\circ} 13.465 / 17$. Para esta análise foi realizado um levantamento bibliográfico da doutrina e legislação brasileiras. Ao final, este artigo buscou comprovar que esse modelo partiu cronologicamente de uma ilegalidade para uma aparente legalidade, necessitando, ainda, de interpretações jurídicas e alterações legislativas (federal ou municipal), para se adequar ao planejamento urbano democrático das cidades. Em virtude dessa constatação, o presente artigo buscou, ainda, dar contribuições no sentido de sugerir questões relevantes que poderão ser estabelecidas como condicionantes e compensações, quando da edição das leis municipais, que versem sobre o tema.

Palavras-chave: Alphaville. Loteamentos. Direito. Planejamento urbano.

\section{ABSTRACT}

The purpose of this article is to understand the Alphaville Urbanismo S.A company's mode of operation, in the light of the national regulatory system, seeking to verify their (i)legality. The interest of the research was based on the finding of possible social and environmental setbacks in the approval and execution of Alphaville's entreprises, when compared to Allotments traditional subdivisions (open Allotments) , governed by Federal Law 6.766/79, which are obliged to donate areas to the use of the general population. It was essential to compare the object of this article with the rules and principles of law, including the new institutes created by Federal Law $n^{\circ} 13.465 / 17$. For this analysis a bibliographic survey of Brazilian's doctrine and legislation was carried out in the end, the research proves that this model has chronologically departed from an illegality to an apparent legality, necessitating, also, legal interpretations and legislative changes (federal or municipal), to fit the democratic urban planning of cities. In view of this observation, the present article also sought to make 
contributions in order to suggest relevant issues that may be established as conditions and compensations, when the edition of municipal laws, which deal with the theme.

Keywords: Alphaville. Allotments. Right. Urban planning.

\section{INTRODUÇÃO}

Os espaços residenciais fechados, ao estilo Alphaville, não são um fenômeno isolado, mas a versão residencial de uma nova forma de segregação nas cidades contemporâneas. Fazem parte de uma categoria mais ampla de novos empreendimentos urbanos denominados "enclaves fortificados", posto que são propriedades privadas para uso coletivo e enfatizam o valor do privado e restrito, ao mesmo tempo desvalorizam o que é público e aberto na cidade. Fisicamente são demarcados e isolados por muros, grades, espaços vazios e fachadas que guardam entre si uma aparente harmonia. São controlados por fortes sistemas de segurança, com regras de inclusão e exclusão. Prestam-se para atender aos desejos materiais e simbólicos dos estratos médios e altos da sociedade e têm contribuído para alterar significativamente o desenho urbano das cidades, ressaltando um padrão de segregação espacial que dificulta a interação entre as distintas classes que são impedidas de usufruir dos mesmos espaços de moradia, aumentando, assim, a tensão entre elas (CALDEIRA, 2016).

A proliferação desses empreendimentos tem influenciado a relação das pessoas com o espaço público, estimulado "a negação da rua" e provocado um novo uso do solo das áreas periféricas da cidade, gerando, assim, a configuração de uma nova estrutura urbana (BARROSO, 2015). Vive-se cada vez mais em cidades divididas, fragmentadas e propensas a conflitos. O modo como o mundo é visto e definido depende do lado da pista ou do muro em que os indivíduos se encontram e do tipo de consumismo a que têm acesso (HARVEY, 2014).

A escolha da marca Alphaville, como objeto deste artigo ${ }^{1}$, decorreu do fato de ser a pioneira na criação de loteamentos fechados e por ser, ainda hoje, a maior empresa do ramo de construção de empreendimentos residenciais horizontais fechados, bem como por utilizar uma estratégia de marketing relacionada ao status social e à segurança. Assim, a Alphaville serve de importante fonte para análise dos aspectos materiais e simbólicos envolvidos nesses empreendimentos. Outro fator

\footnotetext{
${ }^{1}$ Artigo desenvolvido como produto da dissertação: SILVA, Leon Delácio de Oliveira e. Da ilegalidade à aparente legalidade na produção do espaço urbano: o caso dos empreendimentos da Alphaville Urbanismo. Dissertação (Mestrado). 2018. Universidade Federal de Pernambuco, Centro de Artes e Comunicação, Programa de Pósgraduação em Desenvolvimento Urbano. Disponível em: https://repositorio.ufpe.br/handle/123456789/34051.
} 
relevante na delimitação do objeto da pesquisa foi o fato de que a referida empresa aprova e executa seu modelo, através de um modus operandi próprio (que são suas características principais) que possibilita maior rentabilidade e celeridade, permitindo, assim, grande capilarização do seu produto principal em extensas áreas do território nacional.

O interesse deste artigo decorreu da constatação de possíveis retrocessos socioambientais na aprovação e execução dos empreendimentos da Alphaville, quando comparados com os loteamentos tradicionais (abertos), regidos pela Lei Federal no 6.766/79, que obrigam os empreendedores a doar áreas ao Poder Público, para uso da população em geral.

O objetivo é compreender o modo de operação da Alphaville Urbanismo S.A. à luz do ordenamento jurídico pátrio, fazendo o paralelo com os recentes institutos criados pela nova Lei $n^{\circ}$ 13.465/17 (condomínios de lotes, loteamento de acesso controlado, Regularização Fundiária Urbana de Interesse Específico), buscando verificar sua (i)legalidade.

Ao fim, após a exaustiva análise crítica doutrinária e legal sobre o tema, partindo da realidade consolidada, buscar-se-á interpretá-la de forma racional sem desvencilhar das normas e dos princípios protetivos da cidade, com o intuito de buscar medidas mais adequadas, razoáveis, humanas e democráticas, que possam minimizar os efeitos sobre o meio ambiente urbano e a coletividade.

\section{O ESTILO ALPHAVILLE DE MORAR}

\section{Da gênese do estilo Alphaville}

A conjuntura de crise urbana decorrente da Revolução Industrial teve diversas consequências. O quadro de intensas transformações sociais, demográficas e econômicas daquele momento resultou numa cidade de extensão territorial até então desconhecida, com uma população e densidades inéditas. O reconhecimento da forma urbana e edilícia como partes intrínsecas da questão social e moral da crise urbana da segunda metade do século XIX ajudariam a criar uma imagem da cidade como doença e caos. Contra essa imagem negativa da cidade, seriam apresentadas críticas e contrapropostas de outros modos de urbanização que, por diversas vezes, encontraram no inverso da realidade compacta, a alternativa na cidade dispersa.

Algumas propostas urbanísticas desenvolvidas a partir da segunda metade do século XIX até o início do século XX, momento de constituição do campo disciplinar do Urbanismo, incorporaram a dispersão definitivamente ao repertório projetual da cidade, dentro das mais diversas intenções, interpretações e dimensões. 
A Broadacre City foi proposta em 1934 por Frank Lloyd Wright como uma radicalização da dispersão como princípio urbanístico. Sua crítica à grande cidade adensada e sua defesa ao individualismo norte-americano formaram as bases conceituais do projeto, sendo ela a contraproposta de Wright à urbanização e industrialização dos Estados Unidos da América (EUA). Para Wright, as centralidades seriam fortemente diluídas, e, em alguma medida, os equipamentos urbanos espalhados pela cidade assumiriam este papel como locais de encontro e socialização, formando núcleos menores de convívio comunitário. Wright almejava a liberdade quase absoluta do indivíduo e a democratização equitativa expressa em um esquema urbanístico completamente descentralizado e disperso pelo território (CHOAY, 1992).

Nos anos 1960 e 1970, também nos EUA, a partir de um plano geral de oferta de bairros específicos para lazer e veraneio, foram construídos vários condomínios exclusivos, conhecidos por gated communities. Esses locais podem ser considerados os primeiros ambientes onde os norteamericanos puderam criar espaços cercados ou wall themselves off. Cabe registrar que, no contexto norte-americano, a expansão dos subúrbios tem uma característica especial: o uso intensivo da propaganda ressaltando o estilo de vida, não sendo a insegurança o fator predominante. Outra característica americana é o fato desses locais não serem fechados por muros e grades (D'OTTAVIANO, 2008).

Assim, não se tratava apenas de uma fuga do caos urbano, e sim da busca por um estilo de vida próprio. Desse modo, as casas no subúrbio americano com seu novo estilo de viver são vendidas como o ideal norte-americano de vida, conhecido por american way of life. Com a incorporação de valor, através do discurso da publicidade, os subúrbios passam, então, a ser zonas residenciais valorizadas, onde pessoas com alto poder aquisitivo passam a querer viver. Tratavam-se de bairros etnicamente homogêneos que vendiam a oportunidade de se morar em comunidade, entre iguais.

Percebendo um propício ambiente para expansão do capital, o setor imobiliário passa a utilizar à sua maneira o conceito da Broadacre City, apresentando ao mercado consumidor de alta renda um modelo de desenvolvimento urbano com forte influência norte-americana, que, através de grande apelo publicitário, cria um novo estilo de morar ligado ao american way of life. Esse novo produto, ao ser inserido no modelo fordista (de produção em série) de desenvolvimento capitalista, passa a ser expandido para outros países, sendo transplantado para a América Latina, incluindo o Brasil, reforçando-se os laços de dependência geopolítica e, obviamente, abrindo novas oportunidades para o capital imobiliário. 
No caso do Brasil, esse fenômeno de construção de conjuntos de moradias fechadas reportando ao modelo ideal americano é recente: apesar do primeiro Alphaville reportar ao início da década de 1970, apenas na década de 1980 esse modelo começa a se expandir gradativamente.

No contexto nacional, a primeira grande empresa a propor esse formato foi a Construtora Albuquerque Takaoka (atualmente, Alphaville Urbanismo S.A.), no início da década de 1970, quando construiu o primeiro Alphaville Residencial, buscando atender às necessidades dos executivos das empresas instaladas no Centro Industrial e Empresarial Alphaville, em Barueri/SP. O padrão de desenho urbano proposto pela empresa remete a uma certa imagem do subúrbio norte-americano, em conjuntos residenciais horizontais, próximos da natureza, distantes dos centros urbanos tradicionais, porém acessíveis através das rodovias, e que valorizam a homogeneização - os entre iguais. A marca Alphaville busca, ainda, agregar ao imóvel o valor imaterial relacionado ao desejo de se viver em uma sociedade ideal, na qual inexistam problemas sociais, como, por exemplo, a insegurança, bem como valoriza os aspectos da distinção social, através de recursos publicitários.

Na visão de Pellegrino (1995), esse modelo considerado de "primeiro mundo" é transplantado já ultrapassado, entre uma visão do que seja "arcaico" e "moderno", com o choque temporal entre contextos culturais e tecnológicos descontínuos. Este padrão de progresso chega às terras brasileiras com enormes e multicoloridos painéis publicitários e toda visão tecnófila, em completa indiferença com a paisagem natural e os condicionantes ambientais originais, adotando-se normas plásticas arquitetônicas e paisagísticas já superadas no "primeiro mundo".

\section{O modus operandi Alphaville}

O início da Alphaville Urbanismo S.A. ocorre com a construtora Albuquerque Takaoka, que foi fundada em 1951 e, posteriormente, em 1994, transformou-se na empresa Alphaville Urbanismo S.A. Ainda na década de 1970, a Construtora criaria o conceito de "condomínio clube" através do lançamento do Conjunto Ilhas do Sul, na cidade de São Paulo, inspirado no modelo das gated communities americanas. Paralelamente, a Construtora em 1972 adquire terras de parte da Fazenda Tamboré, localizada no Município de Barueri, na Região Metropolitana de São Paulo e nele constrói o "Alphaville Residencial" e o Alphaville 2, nas proximidades do Centro Industrial e Empresarial de Barueri, lançados em 1976. Em 1979, lançaria o Alphaville 3.

No entanto, a falta de hábito de se morar nesse tipo de empreendimento, quase levou a construtora à falência (VARGAS, ARAUJO, 2014) e foi necessária a intensificação na publicidade imobiliária para que o negócio decolasse na década seguinte e atraísse novos investidores em números 
significativos, expandindo o negócio no vetor sudoeste paulista através da aquisição de terras contíguas aos dos Alphaville residenciais, fragmentando o território em frações menores e empreendendo novos loteamentos, lançados aos poucos, anualmente (SILVA, 2016).

Em 1995, a sociedade entre Renato de Albuquerque e Nuno Lopes Alves faz surgir a Alphaville Urbanismo e inicia o processo de expansão em direção, inicialmente, a Campinas/SP e com a entrada de novos investidores como a Gafisa, no ano de 2006, e da Blackstone e Pátria Investimento, no ano de 2013, quando a empresa passa a lançar empreendimentos em todo o Brasil tornando-se empresa líder nacional em empreendimentos horizontais fechados. A empresa expandiu os seus produtos por mais de 50 cidades, hoje com 124 empreendimentos em 22 estados brasileiros e no Distrito Federal. A empresa tem um portfólio de dois produtos: os empreendimentos Alphaville e Terras Alpha. A companhia também é responsável pelo desenvolvimento da Cidade Alpha, núcleos urbanos menores que uma cidade, mas maiores que um bairro, a exemplo do de Barueri e Brasília.

É possível dividir a atuação da Alphaville Urbanismo em dois formatos: a) construção de "residenciais" e b) "núcleos urbanos". Tendo em vista a facilidade e celeridade nos empreendimentos apenas residenciais, esse modelo tem sido a regra de expansão em todo o território nacional.

Embora localizados em realidades sociais distintas, a lógica de reprodução da Alphaville Urbanismo, ou seja, seu modus operandi apresenta, via de regra, características em comum, como, por exemplo: a) busca por terrenos mais baratos na periferia para incorporação imobiliária; b) parceria entre promotores imobiliários, grandes proprietários de terra e o Estado; c) localização próxima aos grandes eixos rodoviários de mobilidade; d) aprovação como loteamentos abertos, com base na Lei $n^{\circ}$ 6.766/79 e nas legislações municipais de parcelamento do solo; e) cessão das áreas doadas ao Poder Público, através de concessões ou permissões de uso dos bens públicos, para as referidas associações, e o consequente fechamento das áreas públicas; e f) criação de uma associação por empreendimento para assumir a gestão e manutenção, assegurando o "padrão Alphaville".

Segundo Guerra (2013, p. 20):

Apesar de localizados em realidades sociais distintas, a lógica de produção
desses empreendimentos apresenta características em comum, como a busca
por terrenos mais baratos na periferia para incorporação imobiliária, a
associação entre promotores imobiliários, grandes proprietários de terra e o
Estado, e o uso de um discurso simbólico para promover um novo estilo de vida.

Com esse modo de operação, a Alphaville Urbanismo S.A. criou "um verdadeiro produto imobiliário em série", expandindo sua marca para todo o território nacional, independentemente das 
características locais onde se instale. Passamos agora a discutir como se estrutura cada uma das características acima elencadas.

\section{A escolha por áreas mais baratas}

A principal e mais notória característica é a manutenção da localização periférica de seus empreendimentos, sempre situados em áreas de expansão urbana, áreas estas que, muitas vezes, eram consideradas rurais pela legislação municipal até o momento em que a empresa e seus parceiros decidiram iniciar um novo negócio e propuseram a alteração de uso do solo às prefeituras.

Tanto Alphaville Barueri/SP quanto Alphaville João Pessoa/PB, por exemplo, foram criados em antigas fazendas. No primeiro caso, a distância da localidade por si só tornava a terra barata. No segundo caso, apesar de encravado em área próxima do centro tradicional, encontrava-se em área de grande restrição ambiental, o que, consequentemente, limitava os índices construtivos e diminuía o valor da terra.

Por serem áreas mais baratas, permitem maior margem de negociação e parceria com os proprietários de terras em sua aquisição, bem como possibilita grande margem de lucratividade nas vendas, após a valorização ocorrida pelas construções das áreas de lazer e demais áreas comuns e, sobretudo, quando a marca Alphaville agrega valor ao produto.

\section{Parceria com os proprietários de terras}

O estabelecimento de parcerias com proprietários de terras locais é uma prática comum nos empreendimentos. Os parceiros entram no negócio com as terras e recebem um determinado número de lotes, cerca de $30 \%$ do total de lotes a depender de avaliação, como contrapartida financeira. Essa estratégia facilitou a entrada da Alphaville em muitas regiões do País, pois vários parceiros procuram a empresa diretamente para oferecer suas terras, antes mesmo da Alphaville demonstrar interesse em empreender novos loteamentos em certas cidades.

\section{Proximidade com as rodovias}

O fator localização é um dos pilares dos empreendimentos da Alphaville Urbanismo, seja criando um novo centro (Alphaville Barueri e Alphaville Brasília), estando próximo dos centros tradicionais (Alphaville João Pessoa) ou permitindo o rápido deslocamento para as áreas centrais, 
através de veículos automotivos individuais (Alphaville Paraíba, Alphaville Francisco Brennand, Alphaville Pernambuco e Alphaville Pernambuco II). Este último modelo é o mais comum da empresa.

A localização afastada dos centros tradicionais e próxima das rodovias tem permitido à empresa maior facilidade e menor custo na aquisição de novas áreas para construção de novos empreendimentos. A marca percebeu que era mais célere e vantajoso concentrar esforços apenas na construção das moradias e nas áreas de lazer interna, apropriando-se das áreas centrais a partir da localização próxima às rápidas vias de acesso de transportes individuais, principalmente as rodovias. Ao marketing coube o papel de convencer o público alvo sobre as vantagens de morar em um Alphaville, ainda que a quilômetros de distância da zona central.

\section{Aprovação como loteamento tradicional}

Os empreendimentos da Alphaville são aprovados nas prefeituras como loteamentos tradicionais, com base na Lei Federal $n^{\circ} 6.766 / 79$, que dispõe sobre o parcelamento do solo urbano, e nas leis municipais de parcelamento do solo.

Até os dias de hoje, o enquadramento jurídico dos empreendimentos da Alphaville é um tema tormentoso na doutrina e nos tribunais. A Alphaville Urbanismo S.A. aprova seus empreendimentos como loteamentos tradicionais, ou seja, abertos, porém, posteriormente, realiza o fechamento das áreas públicas.

Do fechamento das áreas públicas através de concessões ou permissões de uso de bem público

Após a aprovação como loteamento tradicional, buscando garantir o fechamento de todo o empreendimento, a Alphaville Urbanismo solicita do Poder Público municipal a concessão ou permissão de uso, gratuita, dos bens públicos doados a título de arruamento, áreas verdes e de equipamentos comunitários.

O que se verifica é a utilização de institutos jurídicos que permitem a cessão de uso de bens públicos de uso comum do povo (ruas, praças, áreas verdes, etc.) para a associação de moradores de cada empreendimento da Alphaville, permitindo o uso privativo, desvirtuando a finalidade principal do bem (ruas são fechadas e as áreas de convívio coletivo são exclusivas). A cessão de uso de bem público é um ato administrativo discricionário do Poder Público, possibilitando (e não obrigando) que o agente público, no juízo de conveniência e oportunidade, conceda ou não o ato, sempre respeitando o interesse público e a legislação. Por essa razão, ou a Alphaville realiza propaganda enganosa (artigo 
37, §1ํㅡ, do Código de Defesa do Consumidor) ou possui excesso de confiança na sua relação com o Poder Público, pois, mesmo diante de um ato discricionário, coloca como uma de suas cláusulas contratuais que: "envidará seus melhores esforços, para obter das autoridades governamentais competentes ato administrativo, ou mesmo para celebrar contrato administrativo que possibilite o fechamento do perímetro da área residencial do Loteamento", conforme se verifica pela leitura da Cláusula Vinte e Três do Instrumento Particular de Promessa de Compra e Venda de Imóvel Objeto de Loteamento (Figura 01), abaixo:

Figura 01 - Cláusula Vinte e Três - Fechamento do Perímetro da Área Residencial do Loteamento

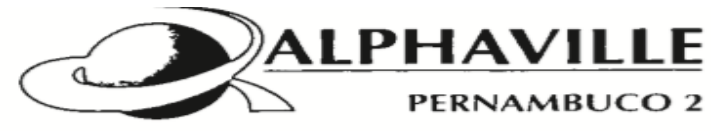

Quadro Resumo, em caráter irrevogável e irretratável, o qual fica investido dos poderes para, no impedimento de qualquer COMPRADOR ou de todos, e em seu nome, receber $e$ atender citações, notificaçōes, intimaçōes, circulares, avisos, cartas e comunicaçōes, relativas a esta Promessa de Venda e Compra, especialmente no caso de execuçāo deste.

IIL3. A VENDEDORA, neste ato, ratifica os poderes conferidos à ALPHAVLLE, em caráter irrevogável e irretratável, na forma do art. $\mathbf{6 8 4}$ do Código Civil, para receber e dar quitação da parte do preço do Lote que the é devida, podendo transigir e firmar acordos, compromissos, confessar, renunciar direitos, rescindir a Promessa, judicial ou extrajudicialmente, contratar advogados outorgando-thes os poderes ora conferidos, no todo ou em parte, inclusive para o foro em geral.

\begin{abstract}
CLAUSULA VINTE E TRÉS - FECHAMENTO DO PERIMETRO DA AREA REsidencial do LOTEAMENTO.

A ALPHAVILLE tomará as providências necessárias e cabiveis, envidando seus melhores esforços, para obter das autoridades governamentais competentes ato administrativo, ou mesmo para celebrar contrato administrativo que possibilite o fechamento do perimetro da área residencial do Loteamento ("Ato Administrativo" ou "Contrato Administrativo"), de forma a permitir o controle de acesso ao interior da área residencial do Loteamento.

Obtido o Ato Administrativo ou celebrado o Contrato Administrativo com as autoridades governamentais competentes, a ALPHAVILE executará as obras necessárias para o fechamento do perimetro da área residencial do Loteamento, na forma do Memorial das Obras do Loteamento, por meio de muro, alambrado, gradil ou cerca, que poderá ocupar áreas públicas e privativas, limitrofes dos lotes confrontantes com o referido perimetro, sem ensejar aos proprietários dos respectivos lotes direitos a indenizaçāo de qualquer natureza.

O Ato Administrativo ou o Contrato Administrativo, conforme o caso, em razāo da respectiva natureza legal, poderá nāo caracterizar direito adquirido dos proprietários de lotes do Loteamento.

O fechamento uma vez autorizado pela autoridade competente, não significa o fechamento do Imóvel e sim do perimetro da área residencial do Loteamento com o consequente controle de acesso, nos termos do disposto neste instrumento.
\end{abstract}

Fonte: Alphaville Urbanismo, 2017.

Essa prática de cessão de utilização de áreas públicas destinadas a praças, ruas e equipamentos comunitários para uso privativo dos moradores do Alphaville apresenta desvirtuada a finalidade pública dos bens, posto que o uso privativo do bem público é excepcional, só devendo ser permitido se estiver compatível com finalidade principal do bem e respeitar o interesse público primário. Em regra, deve prevalecer a indisponibilidade do interesse público, portanto, apesar da possibilidade jurídica do consentimento de uso privativo de bem público por particular, é importante que a 
Administração Pública considere a impossibilidade de dispor do bem público como the aprouver e que não devem ser valorizados interesses privados de particulares específicos em detrimento dos interesses de toda a coletividade (DI PIETRO, 2004).

Di Pietro (2010) afirma que o uso privativo do bem público, apesar de possível, só deve ser outorgado se estiver compatível com a finalidade principal do bem:

O uso, seja ele comum ou privativo, deve sempre ser exercido sem prejudicar ou impedir a consecução do fim principal a que o bem está afetado. Desta forma, pode o particular, munido de título jurídico, utilizar-se privativamente de trecho de rua para instalar banca de jornal; mas esse uso, que incide sob pequena parcela do bem dominial, só pode ser concedido na medida que não impeça ou dificulte a livre circulação, já que tal é o fim precípuo a que se destina esse bem de uso comum do povo (DI PIETRO, 2010, p. 18).

Independentemente das mencionadas críticas, a Alphaville Urbanismo adota como mecanismo de operação a aprovação como loteamento tradicional (aberto), posteriormente, consegue a cessão de uso das áreas públicas ao Poder Público local e realiza o fechamento total do empreendimento.

\section{Constituição de associações para manutenção do padrão}

Buscando manter o padrão da marca Alphaville, em cada empreendimento é criada uma associação (pessoa jurídica de direito privado sem fins lucrativos) constituída pelos moradores, que servirá como verdadeira guardiã dos valores do modelo da Alphaville.

O grande traço diferenciador da Alphaville para as demais empresas concorrentes é justamente a supervalorização do chamado "padrão Alphaville", que leva em consideração a organização e manutenção dos empreendimentos. Esse padrão não é mantido diretamente pela empresa, mas através das associações que são criadas em cada empreendimento.

A autogestão garante o padrão Alphaville nos empreendimentos. Mantida pelos proprietários, a Associação Alphaville é responsável pela contratação de pessoal, manutenção física, segurança e administração do clube. A formação da diretoria ocorre por meio de eleições realizadas a cada dois anos. A associação também é responsável pela fiscalização das normas construtivas e de ocupação repassadas pela Alphaville, com o objetivo de manter a excelência urbanística dos empreendimentos (SILVA, 2016 p. 259). 
Trata-se de uma articulada (e econômica) estratégia de manutenção dos padrões urbanísticos que caracterizam o modelo definido pela Alphaville, garantindo que todos os empreendimentos continuem servindo como plataforma de propaganda para projetos futuros.

Assim, o tão conhecido "padrão Alphaville", mantido pelas associações, agrega valor à marca como um todo, possibilitando que a empresa seja reconhecida como o grande nome do setor nacional, tendo seus empreendimentos lista de espera para aquisição dos lotes. O sonho de morar em um Alphaville é objeto de desejo de um grande número de consumidores abastados.

De todas as características que compõem o modus operadi do empreendimento, não resta dúvida que a mais intrigante é a cessão de áreas públicas para o usufruto condominial. Esse modelo permite que as áreas, que deveriam ser de acesso ao público em geral, tornem-se, por uma verdadeira "mágica", de uso exclusivo dos moradores, sem quaisquer condicionantes e compensações, sobrepondo os interesses individuais aos interesses coletivos e servindo como mecanismo de distinção e homogeneização das classes.

\section{A ALPHAVILLE URBANISMO E O ORDENAMENTO JURÍDICO PÁTRIO: DA ILEGALIDADE PARA APARENTE LEGALIDADE}

Nessa seção, busca-se apresentar o enquadramento cronológico do objeto de estudo no ordenamento jurídico pátrio. Para essa análise foi necessário tomar como base os empreendimentos da Alphaville a partir do seu modus operandi, que possibilitou sua expansão em série.

A empresa Alphaville Urbanismo S.A. explicita, logo no início de seus contratos (Cláusula Primeira - Loteamento), que o empreendimento se trata de um loteamento, seguindo a Lei Federal $\mathrm{n}^{\circ}$ $6.766 / 79$.

Como demonstrado, a tentativa de enquadramento e aprovação como loteamento tradicional é uma das suas principais características. De fato, pelas dimensões e peculiaridades, os empreendimentos da Alphaville deveriam ser aprovados como loteamento tradicional, possibilitando a expansão ordenada e planejada da cidade. A questão que se coloca é que ela apenas aprova como loteamento tradicional (aberto), porém, em seguida, realiza o fechamento integral com grades e muros.

O loteamento tradicional é regulamentado pela Lei $n^{\circ} 6.766 / 79$, que dispõe sobre o parcelamento do solo urbano. Essa lei conceitua parcelamento do solo para fins urbanos como a divisão da terra em unidades juridicamente independentes, com vistas à edificação, sendo realizado através do loteamento e do desmembramento. Por loteamento entende-se como "a subdivisão de 
gleba em lotes destinados à edificação, com abertura de novas vias de circulação, de logradouros públicos ou prolongamento, modificação ou ampliação das vias existentes" (artigo 2으, §1ํㅡ, da Lei Federal $\left.n^{\circ} 6.766 / 79\right)$.

A gleba parcelada perde sua individualidade e gera lotes com acesso direto à via ou logradouro público, criando novas vias de circulação e logradouros públicos (loteamento). Fato é que o parcelamento do solo urbano presta-se para possibilitar a divisão de grandes áreas (glebas) em lotes destinados à edificação e, consequentemente, oportuniza o crescimento da cidade, sendo, pois, verdadeiro instrumento de planejamento e desenho urbano. Não por outra razão que várias cidades e bairros surgiram a partir de loteamentos.

Assim, diferentemente dos condomínios, no loteamento há uma intervenção direta de grande porte na cidade que necessitará de regras específicas, sobretudo de condicionantes que possam minimizar os impactos negativos na cidade.

A legislação, ciente dos reflexos com a criação de um loteamento, assegurou a necessidade de garantir infraestrutura básica, reserva de áreas para os equipamentos públicos comunitários e áreas verdes, e que as vias de circulação fossem abertas e interligadas. Essas condicionantes decorrem de normas públicas que obrigam o cumprimento daqueles que desejam intervir na cidade através do loteamento.

$\mathrm{O}$ artigo $4^{\circ}$, inciso I, da Lei Federal $\mathrm{n}^{\circ} 6.766 / 79$, expressa que devem estar previstas no projeto dos loteamentos as áreas destinadas ao sistema público de circulação, equipamentos urbanos, equipamentos públicos comunitários e espaços livres de uso público. Em seu artigo 22, estabelece que, desde a data de registro do loteamento, passam a integrar o domínio do município as vias e praças, os espaços livres e as áreas destinadas a edifícios públicos e outros equipamentos urbanos, constantes do projeto e do memorial descritivo.

Desse modo, resta claro que nos loteamentos as vias de circulação (que integram os equipamentos urbanos) e as áreas destinadas aos equipamentos comunitários (como as praças, por exemplo), após aprovação na prefeitura e consequente registro no cartório de imóveis, passam a ser bens públicos de uso comum do povo, de propriedade do município onde foi aprovado o empreendimento, não sendo permitida sua alienação nem mudança de destinação.

O que acontece na prática é que a Alphaville Urbanismo S.A. apenas aprova como loteamento tradicional e, posteriormente, realiza o fechamento de toda a área pública (vias de circulação, áreas verdes e equipamentos comunitários) descaracterizando completamente o instituto. 
Essa simulação não é uma peculiaridade apenas da Alphaville, sendo também realizado por inúmeras outras empresas. Em virtude desse fechamento das áreas públicas nos loteamentos tradicionais, a doutrina passou a denominar esses empreendimentos de loteamentos fechados. Diz-se fechado porque, ao fechar um loteamento, realiza-se uma alteração no projeto inicialmente previsto e aprovado de acordo com a lei federal de parcelamento do solo urbano, Lei Federal $n^{\circ} 6.766 / 79$ (BARROSO, 2015).

Segundo Antunes (2016), nas últimas décadas, constata-se uma tendência em muitas cidades brasileiras que é a construção dos chamados loteamentos fechados, que não são condomínios, pelo fato de as áreas comuns serem públicas e doadas à municipalidade, nem loteamentos tradicionais, pois implicam em um controle de circulação e acesso. O campo não possui uma legislação de regência.

Por muitos anos, a legislação federal pátria não contemplou essa modalidade de parcelamento do solo, que, no entanto, é uma realidade cada vez mais presente nas cidades brasileiras (SARMENTO FILHO, 2008).

Os defensores da legalidade dos loteamentos fechados afirmavam que sua fundamentação se encontrava no artigo 8 o da Lei Federal no 4.591/64, que dispõe sobre condomínio em edificações e incorporações imobiliárias. No entanto, Silva (2010, p. 38), alerta sobre o uso abusivo do dispositivo, uma vez que, na sua leitura, o mesmo daria respaldo para "o aproveitamento de áreas de dimensão reduzida no interior das quadras, que, sem arruamento, permitam a construção de conjuntos de edificações em forma de vilas, sob domínio condominial". Para o referido autor, os loteamentos fechados não existem juridicamente, "configurando uma distorção e uma deformação de duas instituições jurídicas: do aproveitamento condominial de espaço e do loteamento ou desmembramento", tratando-se, portanto, de especulação imobiliária.

Resta claro que, apesar da importância dos condomínios edilícios, seja de apartamentos ou de casas, possibilitarem o melhor aproveitamento do solo urbano, ele não pode ser utilizado como instrumento de planejamento da cidade, sendo imprescindível que sua instalação ocorra em áreas que já foram previamente parceladas, planejadas e incorporadas à cidade, evitando o desordenamento do solo urbano e suas consequências indesejáveis. Nesse sentido, o condomínio edilício não pode ser instituído sobre uma gleba não parcelada e planejada, e sim sobre um lote devidamente servido de infraestrutura básica e já incorporado à cidade.

O condomínio edilício, regido pela Lei Federal no 4.591/1964 e pelo Código Civil, não se constitui como um tipo de parcelamento urbanístico do solo, e sim conjuntos construídos dentro de um mesmo terreno, o qual é propriedade de todos. Pequenos ou grandes conjuntos construídos são 
condomínios quando todo espaço de uso comum, como acessos, ruas, praças, infraestrutura e equipamentos implantados, é propriedade e responsabilidade do conjunto de moradores, os condôminos (OLIVEIRA, 2000).

Segundo Frei (2002), do ponto de vista jurídico, os loteamentos fechados não existiam, pois não havia legislação federal que lhes desse amparo. Para o autor, na verdade, constituíam uma distorção e uma deformação de dois institutos jurídicos: do aproveitamento condominial de espaço e do loteamento tradicional, sendo, a bem da verdade, mais uma técnica supostamente sofisticada de especulação imobiliária, sem as limitações, as obrigações e os ônus que o Direito Público Urbanístico impõe (FREI, 2002).

Assim, apesar da doutrina especializada entender que esses empreendimentos não possuíam amparo jurídico e que o fechamento das áreas públicas era ilegal, os promotores imobiliários continuavam construindo esses empreendimentos e privatizando os espaços públicos, mas agora iriam buscar algum instrumento jurídico que ensejasse maior segurança jurídica. Nesse sentido, em várias cidades brasileiras, os promotores imobiliários passaram a criar associações de moradores para cada empreendimento e barganhavam, junto ao Poder Público, permissões ou concessões de uso das áreas públicas, através de lei ou ato administrativo, com o intuito de realizar o fechamento e a apropriação desses espaços.

No entendimento de Barroso (2015), buscando dar um ar de legalidade a esses loteamentos fechados, alguns municípios têm expedido a permissão de uso de bem público para as áreas públicas incorporadas a esses empreendimentos, com fulcro na possibilidade de uso privativo de bem público por particulares.

Mesmo com essa estratégia, inúmeras ações judicias foram propostas, principalmente pelo Ministério Público, questionando a ausência de interesse público nessa cessão de uso de bem público para um seleto grupo de pessoas e, consequentemente, a constitucionalidade e legalidade dos loteamentos fechados.

Em virtude dos longos anos de questionamentos judiciais, o Supremo Tribunal Federal (STF), em outubro de 2015, por meio do Recurso Extraordinário n 607.940 do Distrito Federal, relatoria do Ministro Teori Zavascki, por deliberação majoritária do Plenário, firmou tese com repercussão geral no sentido de que os municípios com mais de vinte mil habitantes e o Distrito Federal podem legislar sobre programas e projetos específicos de ordenamento do espaço urbano por meio de leis que sejam compatíveis com as diretrizes fixadas no plano diretor. 
A referida tese partiu justamente da discussão sobre a constitucionalidade da lei do Distrito Federal, no uso de sua competência municipal, que dispôs sobre uma forma diferenciada de ocupação e parcelamento do solo urbano em loteamentos fechados, tratando da disciplina interna desses espaços e dos requisitos urbanísticos mínimos a serem neles observados.

A decisão do STF (BRASIL, 2015) concentrou-se em destacar a autonomia municipal na elaboração das leis que tratem sobre novas formas de ocupação e parcelamento do solo urbano, deixando a Corte Suprema de analisar a constitucionalidade dessa nova figura urbanística à luz das normas e princípios constitucionais, urbanísticos e ambientais, que se relacionam com a proteção da cidade.

Informar que os municípios podem criar novas figuras urbanísticas, desde que compatíveis com o plano diretor é tergiversar o verdadeiro debate: são constitucionais os grandes loteamentos que fecham as áreas públicas, que não possuem vias interligadas ao sistema viário e que contrariam o Direito à Cidade?

Apesar de não atingir o cerne principal da questão, fato é que o STF legitimou os municípios a editarem leis municipais que regulamentem os loteamentos fechados. De todo modo, a decisão do STF não permitiu que os municípios passassem a editar leis sem qualquer parâmetro, com o fim exclusivo de regularizar situações ilegais ou dar margem para novos empreendimentos privatizarem áreas públicas. A tese fixada buscou enfatizar a importância de as legislações observarem o plano diretor.

Ao nosso ver, em virtude da coesão dinâmica das normas urbanísticas, deve-se ler a decisão do STF da seguinte forma: as leis municipais que tratarem sobre loteamentos fechados precisam respeitar a Constituição Federal em sua globalidade (em observância ao princípio da unicidade), as leis federais que tratam sobre a política urbana (Lei Federal $n^{\circ} 10.257 / 01$, Lei Federal $n^{\circ} 6.766 / 79$, entre outras) e, sobretudo, o plano diretor, que estabelece as diretrizes do planejamento urbano, sendo possível, para tanto, o estabelecimento de restrições, limitações administrativas e contrapartidas, que possam minimizar os impactos negativos desses empreendimentos sobre a cidade.

Em dezembro de 2016, a Presidência da República editou a Medida Provisória (MP) n 759/16, que foi rapidamente convertida na Lei Federal n 13.465/17, em 11 de julho de 2017, dispondo sobre a regularização fundiária rural e urbana, sobre a liquidação de créditos concedidos aos assentados da reforma agrária, sobre a regularização fundiária no âmbito da Amazônia Legal, bem como instituindo mecanismos para aprimorar a eficiência dos procedimentos de alienação de imóveis da União e dando outras providências. 
Os movimentos sociais criticaram a nova legislação, em virtude da escassez de diálogo e da rápida aprovação. Sob o pretexto da facilitação dos trâmites para a regularização fundiária urbana de interesse social (baixa renda), o que era necessário, foram criados institutos de duvidosa constitucionalidade, como, por exemplo, o loteamento de acesso controlado, que viola os direitos fundamentais de locomoção, de intimidade, entre outros.

Por outro lado, essa nova legislação foi bem aceita pelo mercado imobiliário, que passou a creditar nessa norma o fundamento para legalização e regularização imediata dos loteamentos fechados, ao estilo dos concebidos pela Alphaville Urbanismo S.A.

Por ser uma legislação extremamente recente, existe escassez de material sobre o tema, resumindo-se, basicamente, a alguns poucos artigos e estudos. Desse modo, apenas com o amadurecimento doutrinário natural do tempo será possível a exata compreensão dos institutos. Assim, por óbvio, qualquer análise inicial pode ser prematura, porém não retira sua importância, sobretudo quando busca fomentar o debate sobre o enquadramento jurídico de empreendimentos de grandes empresas ditas "urbanizadoras" nas novas figuras criadas pela recente Lei Federal $n^{\circ}$ $13.465 / 17$, que, certamente, deverá ser objeto enfrentado pelas prefeituras, primeiramente, e pelos tribunais, posteriormente.

Como o presente artigo possui como objeto de estudo os empreendimentos da Alphaville Urbanismo, tomar-se-á por base seu modus operandi, com o intuito de fazer a análise jurídica sobre sua atual legalidade ou não, diante da nova legislação.

Conforme explicitado no tópico anterior, podem-se apontar as seguintes características dos empreendimentos da Alphaville: a) são aprovados como loteamento tradicionais perante as prefeituras e, posteriormente, realizam o fechamento de toda área, com base em uma cessão de uso dos bens públicos; b) realizam verdadeiro parcelamento do solo, em grandes áreas (superiores a várias quadras); c) são construídos sem infraestrutura no entorno, normalmente, em áreas mais afastadas e próximas das rodovias; d) não estão totalmente integrados à cidade; e) as vias internas, por estarem fechadas, não estão interligadas com o sistema viário local; f) os lotes são alienados sem edificação; g) as áreas públicas doadas para os municípios retornam para o empreendimento.

Pelo fato de uma das principais características ser justamente o fechamento total da área, por si só não caberia a utilização do instituto denominado loteamento de acesso controlado, pois, por expressa disposição legal, é vedado o impedimento de acesso a pedestres ou condutores de veículos, mesmo que não residentes. Certamente, esse instituto poderá ser utilizado em loteamentos mais 
populares, porém nos da marca Alphaville fica impossibilitado, tendo em vista que neles o fechamento por muros e grades é integral, sendo impedido o acesso do público em geral.

O loteamento de acesso controlado presta-se para regularizar o que infelizmente se percebe em quase todas as cidades: ruas públicas são fechadas com cancelas pelos próprios moradores, sob o argumento da violência urbana. Esse instituto é de constitucionalidade duvidosa, pois privatiza bens públicos de uso comum do povo (rua), prejudicando a mobilidade urbana da cidade, restringindo o direito à locomoção e de intimidade. $\mathrm{O}$ argumento retórico do texto (“[...] sendo vedado o impedimento de acesso a pedestres ou a condutores de veículos, não residentes, devidamente identificados ou cadastrados") (BRASIL, 1979) não será concretizado na prática, pois as restrições físicas e simbólicas serão efetuadas de forma indiscriminada.

Os entusiastas dos empreendimentos com as características da Alphaville, apostam em outro novo instituto criado pela Lei Federal no 13.465/17, denominado condomínio de lotes, previsto no nos artigos 58 e 78 da mencionada lei. $O$ artigo 58 realizou alteração no Código Civil para incluir o artigo 1.358-A, passando a admitir a possibilidade de adoção do regime condominial para unidades autônomas constituídas de lotes; já o artigo 78, acrescentou o § 70 ao artigo 2 으 da Lei $n^{\circ}$ 6.766/79, para possibilitar ao loteador constituir o lote sob a forma de unidade autônoma ou como unidade imobiliária integrante de condomínio de lotes.

A nova legislação, assim, passou a permitir a criação de um condomínio que será composto por lotes sem necessidade de edificação, os quais estarão, necessariamente, vinculados a uma fração ideal das áreas comuns em proporção a ser definida no ato de instituição. Isso significa que, nesse arranjo espacial, as ruas, as praças e as demais áreas de uso comum não são transferidas à propriedade do município, mas continuam sendo propriedade privada, pertencente aos titulares do lote de acordo com a respectiva fração ideal (OLIVEIRA, 2017).

O condomínio de lotes possui semelhanças com o condomínio edilício, sendo as regras desse aplicado, no que couber, àquele, porém a diferença basilar é que no condomínio de lotes é prescindível a existência de edificação nos lotes. Em virtude das similitudes entre os institutos, as restrições também se operam de modo similar, não servindo o condomínio de lotes, da mesma forma que o condomínio edilício, para substituir as formas de parcelamento do solo (loteamento e desmembramento). 
Cabe ressaltar que o conceito de lote, definido pelo Direito Urbanístico, não foi alterado, não se admitindo a existência de lotes desprovidos de infraestrutura a ser, posteriormente, implantada pelo Poder Público. O conceito de lote aplica-se igualmente aos lotes integrantes de loteamento e de condomínios de lotes.

O que muda é a forma de divisão da quadra resultante do parcelamento. Em lugar de lotes autônomos, poderá ela ser total ou parcialmente organizada mediante a constituição de um ou mais condomínios de lotes, no âmbito dos quais haverá não apenas os lotes propriamente ditos, mas também áreas, edificadas ou não, de propriedade comum dos condôminos, como piscinas, parques infantis, quadras esportivas e vias privadas. Tais áreas, no entanto, não substituem as áreas livres de uso público e o sistema viário constantes do projeto de loteamento, que serão transferidos ao patrimônio público (PINTO, 2017, p. 11-12).

O mesmo autor demonstra, ainda, que o próprio relatório do senador Romero Jucá, na Comissão Mista da MP no 759/16, esclarece justamente essa impossibilidade de substituição do condomínio de lotes pelo loteamento:

Por meio do condomínio de lotes, permite-se que as quadras privadas derivadas do parcelamento do solo sejam organizadas sob a forma de condomínio, independentemente de edificação. Tal sistema não é uma alternativa ao loteamento tradicional, pois em nada altera os ônus a que se encontra submetido o empreendedor. Além disso, assegura-se à prefeitura a prerrogativa de instituir servidões de passagem em benefício dos não moradores e de disciplinar a construção de muros e cercas, com vistas à proteção da paisagem (PINTO, 2017, p. 13)

Desse modo, resta claro que o condomínio de lotes não substitui as formas tradicionais de parcelamento do solo, uma vez que é constituído sobre lotes, ou seja, terrenos derivados de parcelamento anterior, não sendo o fato da existência de vias internas e áreas de uso comum um substituto do sistema viário e das áreas livres de uso público previstas na Lei Federal n 6.766/79.

Nesse sentido, os empreendimentos da Alphaville também não podem, de forma irrestrita, enquadrar-se nessa nova figura, sob pena de ilegalidade, pelas seguintes razões: a) não houve prévio parcelamento urbano do solo e consequente planejamento urbano; b) são empreendimentos de grande extensão, superiores a quadras inteiras; c) as áreas públicas coincidem com as áreas internas; e d) não estão integrados à cidade.

A simples aprovação de extensas áreas desintegradas da cidade, como condomínios de lotes, incidirá nas mesmas vedações constitucionais, legais e principiológicas dos loteamentos fechados, gerando irreparáveis danos à cidade. Dessa forma, o que existe atualmente é uma aparente legalidade. 
A interpretação harmônica e sistemática do ordenamento jurídico para fins de enquadramento dos empreendimentos da Alphaville, em virtude de suas características, seria a necessária realização prévia do parcelamento do solo, nos moldes da Lei Federal $n^{\circ} 6.766 / 79$, com a obrigatória doação de áreas públicas (áreas verdes, equipamentos comunitários e arruamento) e posterior realização de condomínio de lotes, com base na Lei Federal no 13.465/17, dentro de uma das quadras já parceladas.

Essa interpretação seria mais adequada com as normas e princípios protetivos da cidade, sobretudo com o princípio da vedação ao retrocesso socioambiental. Esse princípio, há muito conhecido no Direito Ambiental, atualmente é reconhecido na proteção do meio ambiente urbano. É cediço que a cidade evolui e se modifica constantemente, não podendo o Direito Urbanístico ser uma ciência estanque, ao contrário, deve permitir a mobilidade necessária do arcabouço jurídico que permita uma evolução social, porém sem desgarrar de valores e avanços socioambientais duramente conquistados na preservação do meio ambiente urbano. A observância ao princípio da vedação ao retrocesso presta-se justamente para tal finalidade.

A aplicação do mencionado princípio no objeto de estudo prontamente gera um questionamento: por que motivo, nos loteamentos tradicionais, inclusive nos loteamentos populares, há a obrigatoriedade da doação de áreas públicas destinadas para áreas verdes, equipamentos comunitários e arruamento, devendo essas áreas permanecerem abertas para toda coletividade; enquanto, nos empreendimentos da Alphaville, o Poder Público permite o fechamento?

Certamente, a observância do princípio do não retrocesso socioambiental na aprovação dos empreendimentos da Alphaville não permitiria a simples conduta do fechamento, sem quaisquer estudos, compensações e contrapartidas urbanísticas.

Assim, a utilização do instituto do condomínio de lotes nos novos empreendimentos da Alphaville deve ser realizada dentro das quadras já integradas à cidade, ou seja, posterior ao parcelamento do solo com a consequente doação e registro de áreas em nome do município.

O novo instituto, se bem aplicado, pode ser um importante instrumento para o mercado, sem desrespeitar o ordenamento jurídico pátrio e a função social da cidade.

Cabe ainda registrar que a nova legislação buscou disciplinar não só os novos empreendimentos, mas também os já existentes e irregulares. Nesse sentido, a Lei Federal no 13.465/17 expressa, em seu artigo 13, que a regularização fundiária urbana compreende duas modalidades: a) Reurb de Interesse Social (Reurb-S), que se trata da regularização fundiária aplicável aos núcleos urbanos informais ocupados predominantemente por população de baixa renda; e b) 
Reurb de Interesse Específico (Reurb-E), que é aplicável aos núcleos urbanos informais ocupados por população que não seja da baixa renda.

Dessa forma, seria possível a Reurb de Interesse Específico (Reurb-E) para regularização dos empreendimentos já construídos pela Alphaville, posto que se enquadram no conceito de núcleo urbano informal.

Por não ser de interesse social (baixa renda) e por existirem áreas públicas municipais em seu interior, que no projeto de loteamento original foram destinadas às áreas verdes, equipamentos comunitários e arruamento, será obrigatório o pagamento do justo valor da unidade imobiliária regularizada, a ser apurado na forma estabelecida em ato do Poder Executivo titular do domínio, a título de compensação, com base no artigo 16 da Lei Federal $n^{\circ} 13.465 / 17$, além de outras compensações e restrições urbanísticas e ambientais, que poderão ser exigidas pelo município.

Os adquirentes de boa-fé poderão buscar posterior ressarcimento (direito de regresso) perante os responsáveis pela implantação dos núcleos urbanos informais, bem como a regularização fundiária não eximirá as responsabilidades administrativa, civil ou criminal a quem tenha dado causa à formação dos referidos núcleos urbanos informais (artigo 14 da mencionada lei).

\section{CONTRIBUIÇÕES}

Com a publicação da decisão do STF, no Recurso Extraordinário no 607.940, com repercussão geral, o que torna obrigatória sua observância, e, a partir do advento da Lei Federal n $13.465 / 17$, tecer considerações pela total ilegalidade dos empreendimentos objeto de estudo não teria amparo técnico e jurídico.

Dessa forma, após a exaustiva análise crítica doutrinária e legal sobre o tema, ainda que intimamente se possa desejar outras alternativas e conclusões, partindo da realidade consolidada, buscar-se-á interpretá-la de forma racional sem desvencilhar das normas e dos princípios protetivos da cidade, com o intuito de buscar medidas mais adequadas, razoáveis, humanas e democráticas, que possam minimizar os efeitos sobre o meio ambiente urbano e a coletividade.

Dado alarmante é que inúmeros municípios brasileiros já editaram leis municipais ${ }^{2}$ disciplinando o instituto do loteamento fechado e, certamente, muitos outros seguirão no mesmo

\footnotetext{
${ }^{2}$ Como exemplo de leis municipais que já possibilitavam a criação de loteamentos fechados, podem-se citar: Lei Municipal $n^{\circ} 1.284 / 15$ do município de Porto Seguro/BA, Lei Municipal $n^{\circ} 1993 / 13$ do município de Rio Branco/AC, Lei Municipal n 6.148/12 do município de Rio Verde/GO, Lei Municipal n 3.720/07 do município de Montes Claros/MG e a Lei no 4.893/12 do Distrito Federal. Essa última lei, inclusive, serviu de parâmetro para que o STF, através do Recurso Extraordinário ${ }^{\circ} 607.940$, julgasse a constitucionalidade dessas leis que tratavam
} 
sentido. Todavia, o formato adotado tem sido extremamente benevolente com os promotores imobiliários e pouco tem se preocupado com o planejamento democrático das cidades.

É inquestionável a possibilidade jurídica dos municípios editarem legislações que tratem sobre o tema, seja pelo fato de ser esse ente federado o protagonista pelo planejamento urbano (artigo 182 da (F), seja em observância à autonomia existente entre os entes federados na República Federativa do Brasil (artigo 1ำ da CF). Nesse ponto, não poderia ser outro o posicionamento do STF.

De todo modo, nada impediria que a União, em virtude de sua atribuição constitucional de editar normas gerais em matéria de Direito Urbanístico (artigo 24, inciso I, da CF), assim como o fez com as Leis Federais $n^{\circ 5} 6.766 / 79$ e 13.465/17, alterasse sua legislação e criasse regras mais específicas, rígidas e condizentes com a proteção da ordem urbanística. De fato, melhor seria que a União tivesse criado condicionantes mais claras para os condomínios de lotes, como, por exemplo, a obrigatoriedade da abertura das vias e a doação de áreas para o município, assim como o fez na Lei Federal no 6.766/79. Infelizmente, a nova legislação não apresenta quaisquer condicionantes obrigatórias, restringindo-se apenas a facultar (e não obrigar) aos municípios a instituição de limitações administrativas e direitos reais sobre coisa alheia em benefício do poder público, da população em geral e da proteção da paisagem urbana, tais como servidões de passagem, usufrutos e restrições à construção de muros (artigo 78 da Lei Federal no 13.465/17).

Ainda que a lei federal tenha sido extremamente branda, nada impede que os municípios, através de legislação própria, possam criar novas restrições, condicionantes e compensações urbanísticas e ambientais, com base na leitura conjunta dos artigos 24 , inciso I, $\$ 2 \circ, 30$, inciso I e VIII, e 182 , todos do texto constitucional.

Assim, apontam-se, a título de contribuição, algumas relevantes questões que poderão ser tratadas pelas novas legislações:

a) limitação de tamanho das áreas. Dependendo da dimensão da área, a legislação poderia impor a necessidade do prévio parcelamento do solo, através do loteamento, para posterior realização do condomínio de lotes;

b) distância mínima entre os empreendimentos desse formato;

c) regramento específico sobre os muros e cercas, diminuindo os impactos na paisagem urbana;

sobre loteamentos fechados, oportunidade em que o STF fixou a seguinte tese: "Os municípios com mais de vinte mil habitantes e o Distrito Federal podem legislar sobre programas e projetos específicos de ordenamento do espaço urbano por meio de leis que sejam compatíveis com as diretrizes fixadas no plano diretor". 
d) doação de áreas para o Poder Público destinadas para áreas verdes, de equipamentos comunitários e arruamento no seu entorno ou nas comunidades próximas, correspondente a um percentual de área do empreendimento, assemelhando-se com os percentuais estabelecidos nas leis municipais que tratam sobre parcelamento do solo. A depender das dimensões poderia, ainda, ser exigida a obrigatoriedade na construção e manutenção desses espaços; e

e) estudo técnico embasado sobre o sistema viário local, inclusive utilizando-se de servidões administrativas gratuitas sobre partes dos terrenos privados, para viabilizar a mobilidade urbana.

Em um primeiro momento, pode parecer que essas condicionantes irão inviabilizar o empreendimento, porém é preciso lembrar que nos loteamentos tradicionais o construtor, obrigatoriamente, deve doar extensas áreas à municipalidade (percentual estabelecido nas leis municipais). E mais. É sempre bom recordar duas questões crucias: primeiro, os impactos causados por esses loteamentos fechados, e, segundo, a faculdade de o construtor optar pela utilização de outras formas construtivas, como, por exemplo, loteamento tradicional, condomínio edilício e condomínio de lotes dentro das quadras já parceladas, sem, por óbvio, desvirtuar os institutos.

Cabe registrar que determinadas legislações municipais, que versam sobre o tema, possuem algumas condicionantes louváveis, porém, apenas o amadurecimento do debate com ampla participação popular poderá aperfeiçoar as propostas legislativas. A Lei Municipal $n^{\circ} 3.720 / 07$, do município de Montes Claros/MG, por exemplo, que dispõe sobre o parcelamento do solo urbano e loteamentos fechados, apresentou alguns bons parâmetros, dentre os quais se podem destacar: a) as áreas institucionais e verdes deverão estar situadas externamente ao perímetro do loteamento fechado, numa distância máxima de 100m, não sendo possível que as áreas de lazer e de jardins internas sejam consideradas no percentual de áreas públicas (artigo 44, § 3ㅇ); b) caso as diretrizes viárias apontem a necessidade de abertura das vias posteriormente, estas deverão ser liberadas; c) as calçadas deverão possuir 8,00 metros de largura, sendo parte gramada e arborizada e sua manutenção deverá ser feita pelos moradores; e d) o estabelecimento de tamanho máximo da área desses empreendimentos.

Esse exemplo demonstra que a exigência de condicionantes e restrições, por si só, não inviabilizará novos empreendimentos, ao contrário, adequará a atuação dos promotores imobiliários, com o fim de garantir o desenvolvimento equilibrado da cidade. Esse é justamente o papel da legislação urbanística. 
Cabe, ainda, ressaltar que a mesma legislação poderá estabelecer regras para regularização dos loteamentos fechados existentes, possibilitando, quando necessário, a realização de contrapartidas financeiras destinadas a fundos próprios de planejamento urbano.

Por fim, deve-se enfatizar que propostas de novas leis exigem que se avaliem, com cuidado, as implicações urbanísticas e ambientais que decorrem desses empreendimentos no espaço. É preciso que na edição dessas novas normas o legislador federal ou municipal esteja imbuído do caráter público do Direito à Cidade, bem como a sociedade seja vigilante e participe democraticamente desse processo, pois esses loteamentos fechados precisam ser analisados a partir das normas e princípios do Direito, sendo estabelecidas restrições, limitações e contrapartidas, buscando garantir o bem-estar de todos os seus habitantes, nunca deixando de se questionar: que cidade se quer?

\section{CONSIDERAÇÕES FINAIS}

Este artigo demonstrou as distinções conceituais e jurídicas entre o loteamento e o condomínio edilício, com o intuito de demonstrar a necessidade de condicionantes e regras específicas para cada empreendimento. Como demonstrado, o loteamento é um instituto do Direito Urbanístico, ramo do Direito Público, sendo um instrumento de planejamento urbano, por meio do qual se realiza o parcelamento do solo, integrando extensas áreas vazias à estrutura urbana existente, criando-se lotes menores destinados à edificação. Por outro lado, o condomínio edilício é um instituto do Direito Civil, ou seja, pertencente ao Direito Privado, que não se presta para realizar o planejamento da cidade, ao contrário, é um instituto que deve ser concebido dentro de lotes ou quadras já devidamente integrados à cidade, não podendo ser construído sobre uma gleba não parcelada e planejada.

Certamente, a criação de empreendimentos em grandes extensões, ao estilo da Alphaville, apartado do planejamento urbano, ou seja, sem a destinação de áreas públicas (áreas verdes, equipamentos comunitários e arruamento) e sem a integração com o sistema viário local, ensejará consequências desastrosas para o futuro das cidades. Assim, independentemente da nomenclatura, seja condomínio edilício ou de lotes, há a necessidade do prévio parcelamento do solo, como forma de planejamento urbano.

Dessa forma, a suposta legalização, através da nova figura do condomínio de lotes, dos empreendimentos no modelo da Alphaville, sem quaisquer condicionantes e medidas compensatórias específicas, viola diversos princípios protetivos da cidade, bem como não demonstra a melhor interpretação sistemática e harmônica do ordenamento jurídico pátrio. 
De todo modo, no atual cenário, a partir da decisão do STF, no Recurso Extraordinário no 607.940, e com o advento da Lei Federal $n^{\circ} 13.465 / 17$, simplesmente tecer considerações pela total ilegalidade desses empreendimentos não demonstraria amparo técnico e jurídico, provavelmente não servindo como um estudo que pudesse motivar o debate crítico, coerente e necessário sobre o problema aqui enfrentado. Nesse sentido, a pesquisa teve o cuidado de analisar detalhadamente o enquadramento jurídico dos empreendimentos da Alphaville. A partir disso, foi constatado que esse modelo partiu cronologicamente de uma ilegalidade para uma aparente legalidade, necessitando, ainda, de interpretações jurídicas e, principalmente, alterações legislativas (federal ou municipal), para se adequar ao planejamento urbano democrático das cidades.

Em função dessa constatação, o presente artigo buscou dar contribuições no sentido de sugerir questões relevantes que poderão ser estabelecidas como condicionantes e compensações, quando da edição das leis municipais, que versem sobre o tema. As contribuições elaboradas abrem espaço para novas reflexões e inquietações, lançando perspectivas futuras para o aprofundamento do tema em questão.

Apesar dos muitos aspectos negativos, os empreendimentos da Alphaville mostram-se como uma estrutura consolidada, na qual o mercado imobiliário investe fortemente e que não sofre muita rejeição por parte da população, sendo, inclusive, almejado por grande número de pessoas. Nessa perspectiva, a pesquisa buscou analisar os aspectos normativos e principiológicos do Direito com o intuito de estimular o debate sobre a premente necessidade de interpretações jurídicas e medidas legais que possam, de algum modo, minimizar os efeitos negativos desse modelo.

O que não se pode é simplesmente "fechar os olhos" para empreendimentos que buscam criar "bolsões valorizados" em ambientes sem qualquer infraestrutura externa, sem vias (ruas) interligadas que permitam o deslocamento, sem áreas coletivas que possibilitem a interação das diferentes classes sociais, sob pena de violar os princípios e normas jurídicas.

É necessário pensar a cidade como um todo, considerando que as edificações que possam causar grandes impactos urbanísticos, ambientais e sociais devem ser permitidas com restrições e condicionamentos específicos, sempre em consonância sistêmica com as normas e os princípios do Direito. Cabe ao Poder Público garantir o bem-estar de todos os seus habitantes (presentes e futuros) e ordenar o pleno desenvolvimento saudável e democrático da cidade.

O papel do Poder Público, principalmente do município, no exercício da produção do espaço urbano é primordial. O particular, ainda que esteja atuando na atividade urbanística, deve respeitar o princípio da função pública do urbanismo e da função social da cidade. Assim, ressalta-se o verdadeiro 
papel da legislação urbanística de uso e ocupação do solo como equilibradora entre as forças do mercado e a defesa do bem comum. O Poder Público precisa arcar com a responsabilidade de mediar esses interesses, muitas vezes conflitantes, à luz do bem comum e não dos interesses de um seleto grupo, objetivando assegurar um desenvolvimento urbano mais justo, equilibrado e democrático para todos os cidadãos. É o que se espera de um Estado verdadeiramente democrático.

\section{REFERÊNCIAS}

ALPHAVILLE URBANISMO. Disponível em: https://www.alphavilleurbanismo.com.br/>. Acesso em: 22 jan. 2017.

ANTUNES, Paulo Bessa. Direito ambiental. São Paulo: Atlas, 2016.

BARROSO, Elvira Maria Fernandes. Loteamentos fechados. São Paulo: Baraúna, 2015.

BRASIL. Constituição (1988). Constituição da República Federativa do Brasil. Brasília, DF: Senado Federal, 1988.

. Lei no 6.766, de 19 de dezembro de 1979. Dispõe sobre o Parcelamento do Solo Urbano e dá outras providências. Brasília, DF, 1979.

. Lei no 8.078 de 11 de setembro de 1990. Dispõe sobre a proteção do consumidor e dá outras providências. Brasília, DF, 1990.

. Lei no 10.406, de 10 de janeiro de 2002. Institui o Código Civil. Disponível em: <http://www.planalto.gov.br/ccivil_03/leis/2002/l10406.htm>. Acesso em: 18 abr. 2017.

. Lei no 4.591, de 16 de dezembro de 1964. Dispõe sôbre o condomínio em edificações e as incorporações imobiliárias. Brasília, DF: 1964.

. Supremo Tribunal Federal. Recurso Extraordinário n 607.940. Distrito Federal. Brasília, 29 de outubro de 2015.2 Disponível em: <http://www.stf.jus.br/portal/processo/verProcessoDetalhe.asp?incidente=3823627>. Acesso em: 05 maio 2017.

. Lei no 13.465, de 11 de julho de 2017. Dispõe sobre a regularização fundiária rural e urbana, sobre a liquidação de créditos concedidos aos assentados da reforma agrária e sobre a regularização fundiária no âmbito da Amazônia Legal; institui mecanismos para aprimorar a eficiência dos procedimentos de alienação de imóveis da União; altera as Leis nos 8.629, de 25 de fevereiro de 1993, 13.001 , de 20 de junho de 2014, 11.952, de 25 de junho de 2009, 13.340, de 28 de setembro de 2016, 8.666, de 21 de junho de 1993, 6.015, de 31 de dezembro de 1973, 12.512, de 14 de outubro de 2011, 10.406, de 10 de janeiro de 2002 (Código Civil), 13.105, de 16 de março de 2015 (Código de Processo Civil), 11.977, de 7 de julho de 2009, 9.514, de 20 de novembro de 1997, 11.124, de 16 de junho de 
$2005,6.766$, de 19 de dezembro de 1979, 10.257, de 10 de julho de 2001, 12.651, de 25 de maio de $2012,13.240$, de 30 de dezembro de 2015, 9.636, de 15 de maio de 1998, 8.036, de 11 de maio de $1990,13.139$, de 26 de junho de 2015, 11.483, de 31 de maio de 2007, e a 12.712, de 30 de agosto de 2012, a Medida Provisória no 2.220, de 4 de setembro de 2001, e os Decretos-Leis nos 2.398, de 21 de dezembro de 1987, 1.876, de 15 de julho de 1981, 9.760, de 5 de setembro de 1946, e 3.365, de 21 de junho de 1941; revoga dispositivos da Lei Complementar no 76, de 6 de julho de 1993, e da Lei no 13.347, de 10 de outubro de 2016; e dá outras providências. Brasília, DF, 2017.

. Superior Tribunal de Justiça. Resp n 302.906-SP. Relator Ministro Herman Benjamin. DJe: 01/12/2010. Disponível em: <https://stj.jusbrasil.com.br/jurisprudencia/19133048/recurso-especialresp-302906-sp-2001-0014094-7/inteiro-teor-19133049>. Acesso em: 10 jan. 2018.

Lei no 12.587, de 3 de janeiro de 2012. Institui as diretrizes da Política Nacional de Mobilidade Urbana; revoga dispositivos dos Decretos-Leis $n^{\text {os }} 3.326$, de 3 de junho de 1941, e 5.405, de 13 abril de 1943, da Consolidação das Leis do Trabalho (CLT), aprovada pelo Decreto-Lei no 5.452, de 10 de maio de 1943, e das Leis ${ }^{\text {os }} 5.917$, de 10 de setembro de 1973, e 6.261, de 14 de novembro de 1975; e dá outras providências. Disponível em:

<http://www.planalto.gov.br/ccivil_03/_ato2011-2014/2012/lei/l12587.htm>. Acesso em: 20 maio 2018.

. Lei no 10.257, de 10 de julho de 2001. Regulamenta os arts. 182 e 183 da Constituição Federal, estabelece diretrizes gerais da política urbana e dá outras providências. Brasília, DF, 2001.

CALDEIRA, Teresa Pires do Rio. Cidade de muros: crime, segregação e cidadania em São Paulo. São Paulo: Editora 34; Edusp, 2016.

CHOAY, Françoise. O urbanismo. São Paulo: Editora Perspectiva, 1992. DI PIETRO, Maria Sylvia Zanella. Direito Administrativo. 17. ed. São Paulo: Atlas, 2004.

Uso privativo do bem público por particular. 2. ed. São Paulo: Atlas, 2010.

D'OtTAVIANO, Maria Camila Loffredo. Condomínios fechados na Região Metropolitana de São Paulo: fim do modelo centro rico versus periferia pobre? 2008. 298f. Tese (Doutorado em Arquitetura e Urbanismo) - Universidade de São Paulo, São Paulo, 2008.

FREI, José Carlos. Da legalidade dos loteamentos fechados. 2002. Disponível em: <http://www.ebooksbrasil.org/sitioslagos/documentos/ilegalidade.html>. Acesso em: 28 jun. 2017.

HARVEY, David. Cidades Rebeldes: do direito à cidade à revolução urbana. São Paulo, Martins Fontes, 2013.

MONTES CLAROS. Lei Municipal $\mathbf{n}^{\circ} \mathbf{3 . 7 2 0 / 0 7}$. Dispõe sobre o parcelamento do solo urbano e loteamentos fechados. Montes Claros, MG, 2007.

OLIVEIRA, Carlos Eduardo Elias de. Novidades da lei no 13.465, de 2017: o condomínio de lotes, o condomínio urbano simples e o loteamento de acesso controlado. Brasília: Núcleo de Estudos e Pesquisas/CONLEG/Senado, julho/2017 (Texto para discussão $\mathrm{n}^{\circ}$ 239). Disponível em: <https://www12.senado.leg.br/publicacoes/estudos>. Acesso em: 26 ago. 2017. 
OLIVEIRA, Lisete Assen. Loteamentos, condomínios e formação do espaço público na cidade: o caso de Florianópolis. Trabalho apresentado no XVI Congresso Brasileiro de Arquitetos, Cuiabá, setembro de 2000. Xerografado.

PELLEgRINO, Paulo Renato Mesquita. Paisagens temáticas: ambiente virtual. 1995. 160f. Tese (Doutorado em Arquitetura e Urbanismo) - Universidade de São Paulo, São Paulo, 1995.

PINTO, Victor Carvalho. Condomínio de lotes: um modelo alternativo de organização do espaço urbano. Brasília: Núcleo de Estudos e Pesquisas/CONLEG/Senado, Agosto de 2017 (texto para discussão $n^{\circ}$ 234). Disponível em: <www.senado.leg.br/estudos>. Acesso em: 02 jan. 2018.

SARMENTO FILHO, Eduardo Sócrates Castanheira. Loteamentos fechados ou condomínio de fato. Curitiba: Juruá, 2008.

SILVA, Carolina Pescatori Candido da. Alphaville e a (des)construção da cidade no Brasil. 2016. 261 f. Tese (Doutorado em Arquitetura e Urbanismo) - Universidade de Brasília, Brasília, 2016.

SILVA, José Afonso da. Direito Urbanístico brasileiro. São Paulo: Malheiros Editores, 2010.

VARGAS, Heliana Comin. ARAUJO, Cristina Pereira de. Habitação e dinâmica imobiliária em São Paulo - 1870 - 2010. VARGAS, Heliana Comin. ARAUJO, Cristina Pereira de (orgs). Arquitetura e mercado imobiliário. Barueri: Manole, 2014

\footnotetext{
Sobre os autores:

\section{Cristina Pereira Araujo}

Professora da Pós-Graduação em Desenvolvimento Urbano - MDU e do Curso de Arquitetura e Urbanismo da Universidade Federal de Pernambuco (UFPE). Mestre (2004) e Doutora (2011) em Arquitetura e Urbanismo pela Faculdade de Arquitetura e Urbanismo da Universidade de São Paulo (FAUUSP). Atua na área de Planejamento Urbano e Regional sendo líder dos grupos de pesquisa CILITUR (Cidades Litorâneas e Turismo) e SOPAPO (Sociedade Espaço e Política), ambos sediados no LEP (Laboratório Espaço e Política), vinculado ao PPG em Desenvolvimento Urbano (MDU). Universidade Federal de Pernambuco - UFPE, Recife, PE, Brasil Lattes: http://lattes.cnpq.br/8068366194146208 Orcid: https://orcid.org/0000-0001-9986-5394 E-mail:crisaraujo.edu@gmail.com

\section{Leon Delácio Silva}

Procurador do Município de João Pessoa/PB. Mestre em Desenvolvimento Urbano (UFPE). Pós-graduado em Direito Constitucional. Autor das seguintes obras: "Direito Urbanístico para concursos", pela Editora Juspodivm, "Legislação de João Pessoa Esquematizada" e "Vade Mecum João Pessoa", ambos pela Editora Jusbianch. Foi Procurador do Município de Petrolina/PE. Professor e Advogado. Procuradoria Geral do Município de João Pessoa, Jõao Pessoa,PB, Brasil

Lattes: http://lattes.cnpq.br/6599944561183448 Orcid: https://orcid.org/0000-0001-8025-0912

E-mail:leondelacio@yahoo.com.br

Os autores contribuíram igualmente para a redação do artigo.
} 